\title{
A new bacterial white spot syndrome (BWSS) in cultured tiger shrimp Penaeus monodon and its comparison with white spot syndrome (WSS) caused by virus
}

\author{
Y. G. Wang*, K. L. Lee, M. Najiah, M. Shariff*, M. D. Hassan \\ Aquatic Animal Health Unit, Faculty of Veterinary Medicine, Universiti Putra Malaysia, 43400 UPM, Serdang, Selangor, Malaysia
}

\begin{abstract}
This paper describes a new bacterial white spot syndrome (BWSS) in cultured tiger shrimp Penaeus monodon. The affected shrimp showed white spots similar to those caused by white spot syndrome virus (WSSV), but the shrimp remained active and grew normally without significant mortalities. The study revealed no evidence of WSSV infection using electron microscopy, histopathology and nested polymerase chain reaction. Electron microscopy indicated bacteria associated with white spot formation, and with degeneration and discoloration of the cuticle as a result of erosion of the epicuticle and underlying cuticular layers. Grossly the white spots in BWSS and WSS look similar but showed different profiles under wet mount microscopy. The bacterial white spots were lichen-like, having perforated centers unlike the melanized dots in WSSV-induced white spots. Bacteriological examination showed that the dominant isolate in the lesions was Bacillus subtilis. The occurrence of BWSS may be associated with the regular use of probiotics containing $B$. subtilis in shrimp ponds. The externally induced white spot lesions were localized at the integumental tissues, i.e., cuticle and epidermis, and connective tissues. Damage to the deeper tissues was limited. The BWS lesions are non-fatal in the absence of other complications and are usually shed through molting.
\end{abstract}

KEY WORDS: Shrimp - Penaeus monodon - Bacterial white spot syndrome (BWSS) - White spot syndrome virus (WSSV) B Bacterial disease $\cdot$ Bacillus subtilis $\cdot$ Probiotics

\section{INTRODUCTION}

White spot syndrome (WSS) caused by white spot syndrome virus (WSSV) is a fatal disease that spreads rapidly and causes massive mortalities (Chou et al. 1995, Huang et al. 1995, Wongteerasupaya et al. 1995, Flegel 1997). Since 1992, WSS has spread from East Asia to many Asian countries and more recently to Latin America. WSS was first observed in Peninsular Malaysia in 1994 (Wang et al. 1996); it peaked in 1996, affecting over $80 \%$ of the shrimp farms during the rainy season (from October to February). Through its years of serious impact on the shrimp industry, the

· Corresponding authors. E-mail: wangyingeng@hotmail.com or shariff@vet.upm.edu.my farming community has learned to recognize the typical clinical signs of WSS, i.e., the appearance of white spots on the cuticle. The shrimp die within 3 to $7 \mathrm{~d}$ after the appearance of white spots. As consequent losses are heavy, the appearance of white spots usually compels the farmers to harvest the crop immediately or to destroy the crop to avoid the spread of WSSV to other ponds. During our recent farm visits, however, we encountered instances of shrimp showing similar clinical signs of white spots, but the shrimp were active, in apparently healthy condition and grew normally without suffering significant mortalities. These cases were WSSV-negative when tested with nested polymerase chain reaction (PCR) in the designated national laboratory for WSSV screening, the Aquatic Animal Health Unit at the Faculty of Veterinary Medicine, Universiti Putra Malaysia. Some farms reported good harvest in 
spite of the appearance of clinical signs of white spots even during the early stages of the culture period. These unusual cases were investigated and the white spots were found to be assiciated with bacteria. Thus, the syndrome was referred to as bacterial white spot syndrome (BWSS) and it was compared with WSS.

\section{MATERIALS AND METHODS}

Live tiger shrimp Penaeus monodon showing white spots on their cuticles were collected from 5 commercial farms located in 3 states (Table 1) in Peninsular Malaysia from November 1998 to May 1999. The live shrimp were maintained in aquaria at the Aquatic Animal Health Unit at the Faculty of Veterinary Medicine, Universiti Putra Malaysia, for observation of disease progression and other subsequent studies.

The shrimp in the aquaria were examined daily for the development of clinical signs including external lesions, behavioral changes and mortality. For histopathological study, 15 shrimp from each sample were preserved in Davidson's fixative. The head regions including the cuticles were removed and processed routinely with hematoxylin and eosin (H\&E) staining (Lightner 1996). The cuticular white spots were also examined by wet mount microscopy. In addition, 10 shrimp with cuticular white spots from Samples 3 and 5 were fixed in $4 \%$ glutaraldehyde for transmission electron microscopic (TEM) and scanning electron microscopic (SEM) studies. For TEM examination, cuticles with epidermis and other soft tissues were processed routinely, and ultra-thin sections were stained with uranyl acetate and lead citrate (Hayat 1986). Cuticles showing distinct white spots under light microscopy were mounted on a stub and coated with gold for SEM viewing (Murphy \& Roomans 1984).

The samples were also tested for WSSV, using primers (outer and inner) derived from a DNA fragment conserved for systemic ectodermal and mesodermal baculovirus (SEMBV) and rod-shaped nuclear virus of Penaeus japonicus (RV-PJ) (Takahashi et al. 1996) to perform a 2-tube nested PCR assay. The outer and inner primer pairs amplify products of 816 and 153 bp respectively. The assay also contained a shrimp DNA-specific primer pair that amplifies a 232 bp product to act as false negative indicator. The DNA for the PCR test was extracted from tissues of the head region (excluding the hepatopancreas) using 10 shrimp from each sample. The tissues were fixed in $70 \%$ ethanol, and DNA was extracted using DNAzol $^{\boxplus}$ (Molecular Research Center, USA) according to the manufacturer's recommendation. The amplification was performed in a RapidCycler (Idaho Technology, USA). The PCR products were analyzed by electrophoresis on $2 \%$ agarose gel. After electrophoresis, the gel was stained with ethidium bromide

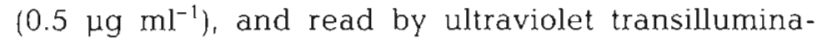
tion.

Bacteria were isolated from the affected carapaces peeled from 10 shrimp each from Samples 3 and 5 in the following manner. The carapaces were homogenized in sterile seawater at a ratio of $1: 9$, and the homogenate was serially diluted to $10^{-1}, 10^{-2}$ and $10^{-3}$, and $0.1 \mathrm{ml}$ of each dilution was spread onto $2 \%$ $\mathrm{NaCl}$ tryptone soya agar (TSA). After incubation at $37^{\circ} \mathrm{C}$ for $48 \mathrm{~h}$, the colonies formed were examined and selected for isolation. These pure isolates were Gram stained to observe their morphology and staining properties. The identity of the Gram-negative bacteria was determined by conventional biochemical tests in combination with a BBL Crystal Kit ${ }^{\mathrm{TM}}$ (Becton Dickinson Microbiology Systems, USA). The assignment to each genus was based primarily on the capacity for growth on TCBS (thiosulphate citrate bile sucrose) agar, oxidase test, sensitivity to vibriostat 0/129, morphology (curved or straight rods) and utilization of glucose. The biochemical tests (amino acid decarboxylase, sugar fermentation, indole and Voges Proskauer test) were performed according to the standard procedures (Cowan 1974, MacFaddin 1980). For the Gram-positive endospore-forming rod-shaped bacteria, the isolates were subjected to tests for oxidase, catalase, motility, sugars (xylose and mannitol), Voges Proskauer and the ability to hemolyse blood agar. The identification of bacterial species was based on Bergey's Manual (Holt et al. 1994) and (Jang et al. 1987).

Table 1. Penaeus monodon. Brief information on the shrimp samples collected for the investigations

\begin{tabular}{|c|c|c|c|c|c|c|}
\hline $\begin{array}{l}\text { Sample } \\
\text { no. }\end{array}$ & Sampling date & $\begin{array}{l}\text { No. of shrimp } \\
\quad \text { (pieces) }\end{array}$ & Location & $\begin{array}{c}\text { Age } \\
\text { (days post-stocking) }\end{array}$ & $\begin{array}{l}\text { Use of } \\
\text { probiotic }\end{array}$ & $\begin{array}{l}\text { Survival rate } \\
\text { at harvest }(\%)\end{array}$ \\
\hline 1 & 28 Nov 1998 & 20 & Perak & 38 & Yes & $\geq 80$ \\
\hline 2 & 4 Dec 1998 & 20 & Johor & 36 & Yes & $\geq 90$ \\
\hline 3 & 5 May 1999 & 30 & Selangor & 40 & Yes & $\geq 80$ \\
\hline 4 & 7 May 1999 & 20 & Selangor & 45 & Yes & $\geq 80$ \\
\hline 5 & 19 Мау 1999 & 30 & Perak & 56 & Yes & $\geq 70$ \\
\hline
\end{tabular}




\section{RESULTS}

\section{Gross signs and histopathology}

The diseased shrimp were active and feeding, except for the appearance of generalized white spots on the cuticle. The shrimp were able to molt without the occurrence of significant mortalities when compared with normal shrimp. The white spots were rounded and not dense. Some had a distinct whitish marginal ring, with or without a pinpoint whitish dot at the center (Fig. 1). Wet mount microscopy revealed BWS as opaque brownish lichen-like lesions with a crenated margin (Fig. 2a). The spot center that appeared darker was actually evidence of a deeper erosion area or perforation due to the destruction of cuticle (Fig. 2b). In certain cases, the perforations were much larger and therefore were readily observed by the naked eye. In many cases, a seta was found at the center of the spots. From the center, numerous lines radiated to the crenated margin, giving rise to the lichen-like profile. These radiating lines were, however, absent in the early stages. The spots seemed to expand from the center, resulting in tiers of homocentric rings. Under higher magnification, numerous bacteria and degenerating hemocytes were found in the matrices of spots (Fig. 2c). The bacteria were concentrated at the spot center.

Histopathological studies revealed no WSSpathognomonic inclusions in any tissue. However, the cuticle, epidermis and connective tissues were infected with bacteria. The section through the spot center revealed perforation of the cuticle, where the underlying cuticular

Figs. 1 \& 2. Fig. 1. (a,b) Bacterial white spots (BWS), which are less dense than virus-induced white spots. Note some BWS have a distinct whitish marginal ring and may be with (arrows) or without (arrowheads) a pinpoint whitish dot in the center. Fig. 2. Wet mount microscopy of BWS. (a) Peeled carapace showing the brownish-discolored, lichenlike BWS with homocentric rings (arrows) and a darkened center (C). Numerous lines (arrowheads) radiate outward from the center to the crenated margin. Scale bar $=215 \mu \mathrm{m}$. (b) BWS undergoing degeneration. The perforation is in the center of the BWS (open arrows), where setae (arrows) were still present. Scale bar $=215 \mu \mathrm{m}$. (c) Peripheral margin of a BWS, showing numerous bacterial colonies (arrowheads) and degenerating hemocytes (arrows) within the white spot focus. Scale bar $=43 \mu \mathrm{m}$
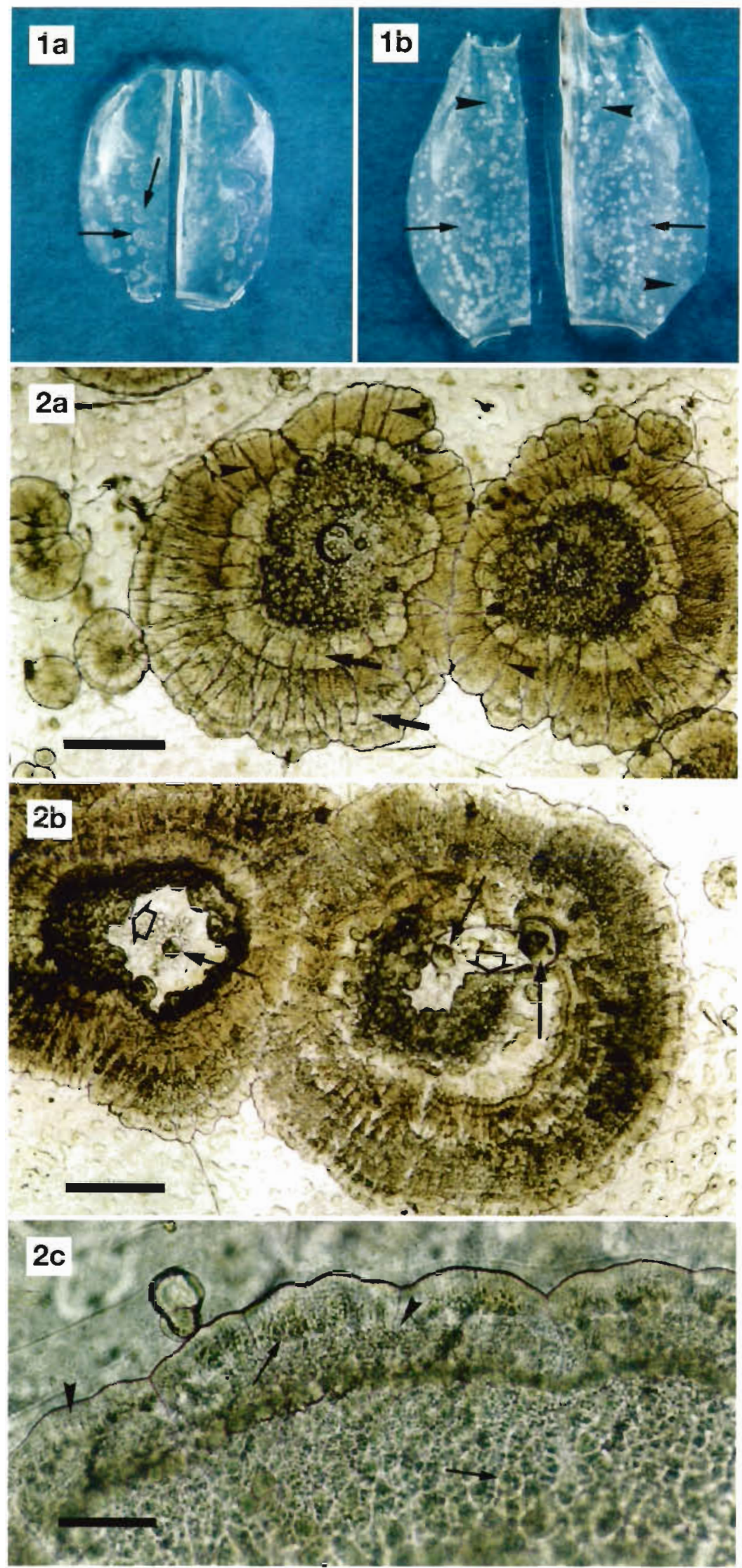

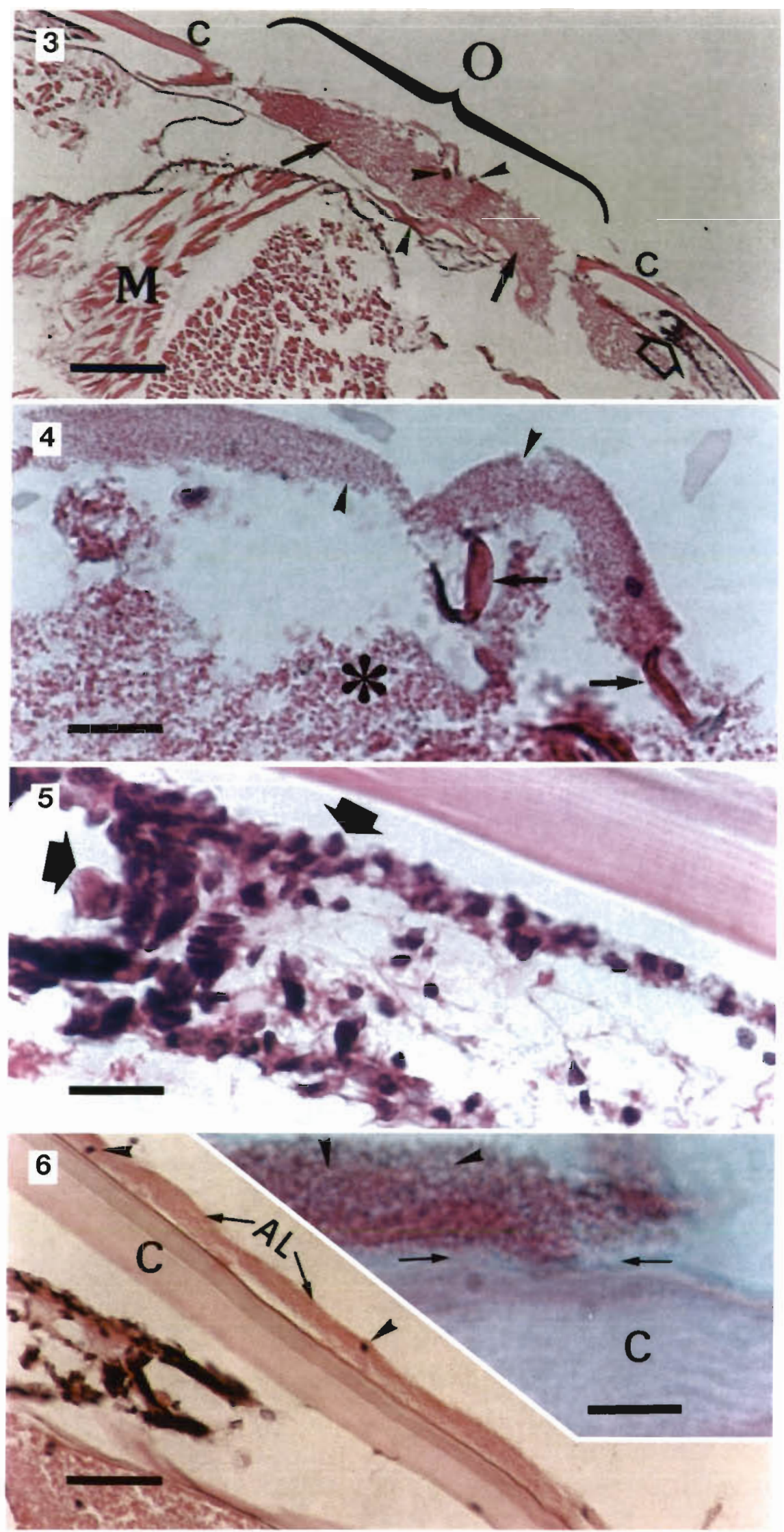

epidermis and connective tissues were replaced by hemolymph, which had infiltrated to seal against the breach and invading bacteria (Figs. $3 \& 4$ ). These bacteria (of external origin) also affected the underlying epidermis and connective tissues adjacent to the perforation leading to necrosis and disintegration of the epidermal lining and connective tissues (Fig. 5). However, the infection was localized and seemed to be non-systemic as there were no pathological changes in the deeper tissues such as muscles. An additional layer consisting of hemolymph and bacteria was found above the epicuticle within the spot foci (Fig. 6). The thickness of this layer was about $1 / 3$ to $1 / 2$ of the normal cuticle. The bacteria were seen to be associated with the degradation and loss of epicuticle, i.e., the outermost layer of the cuticle (Fig. 6 inset).

\section{TEM and SEM observations}

TEM observations did not reveal any WSSV particles and the associated cellular changes in target tissues and

Figs. 3-6. Fig. 3. Cross section of a BWS on an abdominal segment showing the discontinuity of cuticle (C) at the perforated center. The underlying cuticular epidermis and connective tissues are disrupted, and the opening (O) is plugged by infiltrated hemolymph (arrows) The surrounding epidermis and connective tissues display cytopathic effects (open arrow). Note the remains of degenerated cuticle (arrowheads) and the non-affected deeper tissues, e.g., muscle (M). Scale bar $=215 \mu \mathrm{m}$. Fig. 4. Higher magnification of the central opening labeled ' $O$ ' in Fig. 3. The top layer is comprised of bacterial colonies (arrowheads), and the mass underneath is comprised of infiltrated hemolymph $(*)$, Note the remains of degenerated cuticular fragments (arrows). Scale bar $=22 \mu \mathrm{m}$. Fig. 5. Higher magnification of the epidermis and connective tissues adjacent to the opening and indicated with an open arrow in Fig. 3. The micrograph shows a necrotic condition manutested as a dark basophilic mass (arrows). Scale bar $=22 \mu \mathrm{m}$. Fig. 6. An additional layer (AL) consisting of hemocytes (arrowheads) and bacterial colonies, seen above the cuticle $(C)$ within the focus of a BWS. Scale bar $=43 \mu \mathrm{m}$. Inset: Higher magnification of AL showing numerous bacterial colonies (arrowheads). The epicuticle has degenerated and is absent (arrows). Scale bar $=9 \mu \mathrm{m}$ 
organs such as gills, epidermis, connective tissues, antennal gland and muscle as described by Wang et al. (1999). Under SEM examination, the lichenlike spots were toned down and became indistinct due to the preparation. Nevertheless, the spot was detected by the presence of radiating lines, perforations and numerous bacteria on the cuticle surface (Fig. 7). At higher magnifications, the center of the spot appeared as a cavity containing clusters of bacteria (Figs. 8 \& 9). Haemolymph that had precipitated on the cuticle plugging the perforation was also observed (Fig. 10). Within the perimeter of the spot, the epicuticle layer and duct openings of the tegumental glands were eroded, exposing the underlying fibrillar laminae of the endocuticle (the second layer of cuticle), where the bacteria were amassed on the bared fibrils (Figs. 11 \& 12). At high magnification, the bacteria were shown to be mainly bacilliform (Figs. $9 \& 12$ ). The radiating lines were actually fissures formed by the fault planes of layers of fibrillar laminae (Fig. 10).

\section{Nested PCR}

All samples from the 5 farms were shown to be WSSV-negative by the nested PCR assay (Fig. 13). The appearance of the 232 bp shrimp DNA product (false negative control) and $153 \mathrm{bp}$ WSSV DNA product in the positive control confirmed the validity of the results.

\section{Bacterial isolation and identification}

Bacillus subtilis (A1), Flavobacterium odoratum (B1) and Vibrio cholerae (C1) were identified from Sample 3, while B. subtilis (A2), Shewanella putrefaciens (B2) and $V$. cholerae (C2) were identified from Sample 5 (Tables $2 \& 3$ ). Based on bacterial plate counts (Table 4), B. subtilis and $V$. cholerae were the major isolates in both cases, $B$.

Figs. 7-9. Fig. 7. Scanning electron micrograph of the cuticle associated with BWS. Numerous bacterial colonies (*), radiating lines (blank arrows) and perforations (arrows) on the cuticle surface indicate the locations of BWS. Fig. 8. A perforated spot center (open arrow) packed with bacterial colonies. The fibrillar laminae (arrows) of the endocuticle have been exposed as a result of epicuticle erosion. Note the presence of duct openings of tegumental glands (arrowheads) and the remaining epicuticle. Fig. 9. Higher magnification of Fig. 8 showing the presence of different shapes of bacteria in the BWS lesion cavity. Bacilliform types (arrows) are dominant
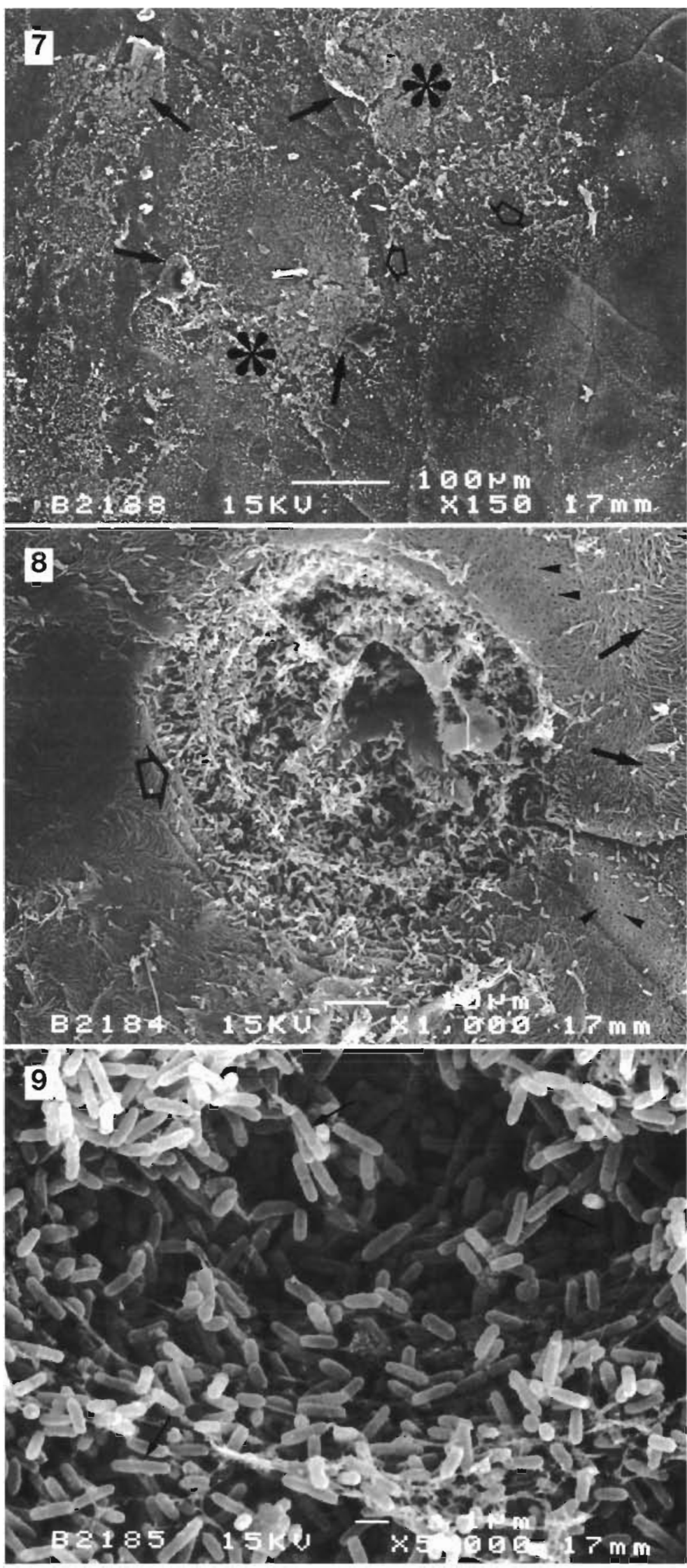

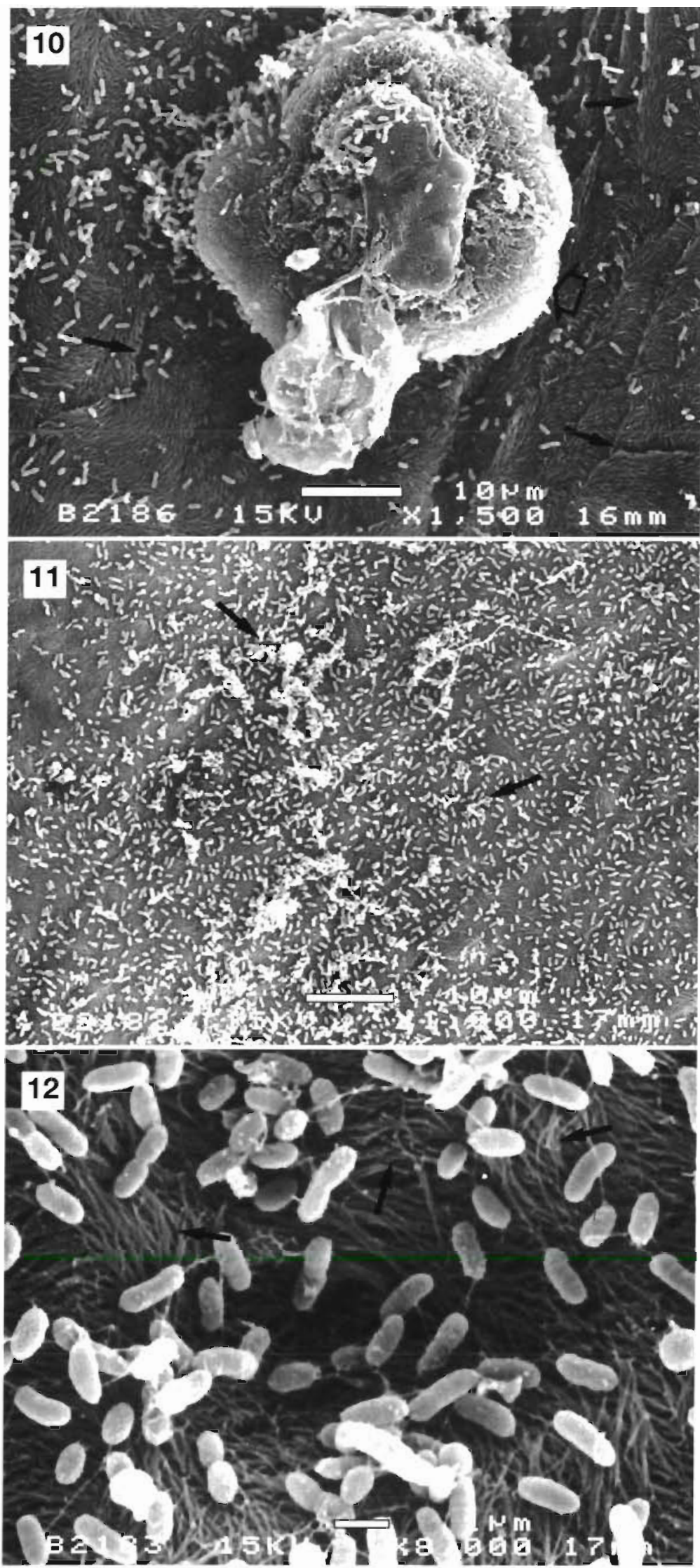

subtilis was, however, the most dominant isolate, which was present in much higher numbers

\section{DISCUSSION}

The bacterially induced white spots appeared at first glance to be identical to those caused by WSSV, but on closer examination the spots could be differentiated based on the following characteristics: (1) BWS is barely visible on the cuticle of live shrimp, but is readily seen on the peeled or molted cuticle, in which the spots are not dense and have a marginal ring with or without a pinpoint whitish dot at the center. In contrast, WSSV induced white spots are dense and easily observable on live shrimp (Fig. 14a). (2) Under light microscopy, BWS have a lichen-like profile with a crenated margin, numerous radiating lines, tiers of homocentric rings, and an eroded or perforated center area in which bacteria are clustered. In contrast, WSSV-induced white spots consists of a marginal ring (sometimes absent) and a central area that contains abundant melanized dots (Fig. 14b). (3) WSSV-infected shrimp usually suffer severe mortalities within a few days of the occurrence of clinical signs. In BWSS no significant mortalities were reported. (4) The BWSSaffected shrimp did not show WSSV particles or typical intranuclear inclusions by TEM and light microscopy, respectively. Furthermore, BWSS shrimp were negative when subjected to a PCR assay for WSSV. Although the white spots described in this study were grossly similar to the white spots caused by WSSV, the etiological agents are apparently different.

Wet mount microscopy, histopathology and SEM consistently revealed heavy bacterial concentrations at the white spot lesions and erosion and perforation of the cuticle. The presence of a seta at the deeply eroded center suggested that the bacterial erosion had started at the seta follicle, where the bacteria could easily localize. The breach in the cuticle apparently resulted in the

Figs. 10-12. Fig. 10. The precipitation (open arrow) of body fluid lodged on the cuticular perforation of a BWS lesion. The radiating lines (arrows) were actually fissures formed by the fault planes of layers of fibrillar laminae. Fig. 11. Presence of a large number of bacteria (arrows) attached to exposed fibrillar laminae. Fig. 12. Higher magnification of Fig. 11 showing the attachment of bacteria to exposed fibrillar laminae (arrows) of the endocuticle 
Table 2. Morphological and biochemical identification tests performed on Gram-positive isolates from white spot lesions

\begin{tabular}{|lcc|}
\hline Test & A1 & A2 \\
& Bacillus subtilis & Bacillus subtilis \\
\hline Gram-staining morphology & Rod with endospore & Rod with endospore \\
Oxidase & + & + \\
Catalase & + & + \\
Motility & + & + \\
Arabinose & + & + \\
Xylose & + & + \\
Mannitol & + & + \\
Hemolyse the blood agar & + & + \\
Voges Proskauer & + & + \\
\hline
\end{tabular}

bacterial infection. We propose that this type of white spot be referred to as bacterial white spot (BWS), and that the disease be called bacterial white spot syndrome (BWSS). In this respect it might be appropriate to refer to the WSS which is caused by virus as VWSS so that it is more readily differentiated from BWSS.

Several species of Vibrio, Aeromonas, Spirillium and Flavobacterium that produce extracellular lipases, proteases and chitinases have been associated with shrimp cuticular diseases such as black spot disease (Lightner 1988). Results of the present study revealed that Bacillus loss of body fluid together with hemocytes that precipitated on the cuticle surface, forming an additional layer on the cuticle. This nutrient-laden layer apparently formed a good substrate to enhance bacterial growth. The thickness of this layer $(1 / 3$ to $1 / 2$ of the thickness of normal cuticle) is believed to be the cause of cuticular discoloration. The presence of multiple homocentric rings and radiating lines originating from the perforation suggests that their formation is related to the periodic or pulsed escape of body fluid and subsequent bacterial growth that gradually spread evenly from the perforation to the adjacent cuticle surface. However, we believe that the initiation of the white spots is associated with erosion of the cuticle by bacterial infection which leads to the release of body fluid. The absence of a central perforation and release of body fluid in some of the spots indicates that initiation of white spot formation does not depend on body fluid escape and precipitation. In many cases, SEM revealed numerous bacteria adhering to the fibrillar laminae of endocuticle confined to the white spot. This suggested that the bacteria could erode or deplete the epicuticle, leading to the degradation and disappearance of this layer, and subsequent exposure of the endocuticle. In summary, the white spots appear to result from degeneration and discoloration of the cuticle following the erosion and disappearance of the epicuticle due to heavy
Table 3. Morphological and biochemical identification tests performed on Gramnegative isolates from white spot lesions. O/F: oxidase/fermentative; TSI: triple sugar iron; SIM: sulphide/indole/motility; VP: Voges Proskauer; +: positive; -; negative; ND: not done; $\mathrm{K} / \mathrm{K}$ : alkaline butt/alkaline slant; $\mathrm{R}$ : resistant; $\mathrm{K} / \mathrm{A}$ : alkaline butt/acid slant; F: fermentative; A/A: acid butt/acid slant; S: sensitive

\begin{tabular}{|c|c|c|c|c|}
\hline Fla & $\begin{array}{c}\text { B1 } \\
\text { lavobacterium } \\
\text { odoratum }\end{array}$ & $\begin{array}{c}\text { B2 } \\
\text { Shewanella } \\
\text { putrefaciens }\end{array}$ & $\begin{array}{c}\text { C1 } \\
\text { Vibrio } \\
\text { cholerae }\end{array}$ & $\begin{array}{c}\mathrm{C} 2 \\
\text { Vibrio } \\
\text { cholerae }\end{array}$ \\
\hline Morphology & $\begin{array}{l}\text { Small } \\
\text { rod }\end{array}$ & $\begin{array}{l}\text { Small } \\
\text { rod }\end{array}$ & $\begin{array}{l}\text { Curved, } \\
\text { small rod }\end{array}$ & $\begin{array}{l}\text { Curved, } \\
\text { small rod }\end{array}$ \\
\hline Gram staining & - & - & - & - \\
\hline Growth on TCBS & - & + & + & + \\
\hline Catalase & + & + & + & + \\
\hline Oxidase & + & + & + & + \\
\hline $\mathrm{O} / \mathrm{F}$ & ND & $\mathrm{F}$ & $\mathrm{F}$ & $\mathrm{F}$ \\
\hline TSI & $\mathrm{K} / \mathrm{K}$ & $\mathrm{K} / \mathrm{A}$ & $\mathrm{A} / \mathrm{A}$ & $\mathrm{A} / \mathrm{A}$ \\
\hline SIM & $-1-1-$ & $+1-1+$ & $-1+/+$ & $-1+1+$ \\
\hline Citrate & - & + & + & - \\
\hline VP & + & + & + & + \\
\hline $0 / 129$ discs & $\mathrm{R}$ & $\mathrm{R}$ & $\mathrm{S}$ & $\mathrm{S}$ \\
\hline Esculin & - & - & + & + \\
\hline Urea & + & + & + & + \\
\hline Glycine & + & + & + & $+1-$ \\
\hline Malonate & - & + & - & - \\
\hline Arginine dihydrolase & + & + & - & - \\
\hline Lysine decarboxylase & + & + & + & + \\
\hline Orthinine decarboxylase & + & + & + & + \\
\hline Arabinose & - & - & - & - \\
\hline Mannose & - & - & + & + \\
\hline Sucrose & - & - & + & + \\
\hline Meliobiose & - & - & - & - \\
\hline Rhamnose & - & - & - & - \\
\hline Sorbitol & - & - & - & - \\
\hline Mannitol & - & - & + & + \\
\hline Adonitol & - & - & - & - \\
\hline Galactose & - & - & - & - \\
\hline Inositol & - & - & - & - \\
\hline
\end{tabular}


Table 4. Bacterial plate counts for various isolates derived from Samples 3 and 5

\begin{tabular}{|llc|}
\hline Sample & Bacteria & cfu $9^{-1}$ cuticle \\
\hline 3 & Bacillus subtilis & $6.0 \times 10^{6}$ \\
& Flavobacterium odoratum & $7.0 \times 10^{5}$ \\
& Vibrio cholerae & $2.7 \times 10^{6}$ \\
5 & Bacillus subtilis & $4.5 \times 10^{6}$ \\
& Shewanella putrefaciens & $6.7 \times 10^{5}$ \\
& Vibrio cholerae & $2.4 \times 10^{6}$ \\
\hline
\end{tabular}

spot lesions. However, the presence of large numbers of bacilliform bacteria seen in BWS lesions by SEM (Fig. 9) and the high bacterial plate counts (Table 4) suggest that $B$. subtilis may be the primary etiological agent. Other bacteria, F. odoratum and Shewanella putrifaciens isolated from the lesions might be second- ary invaders. $B$. subtilis has been reported to excrete enzymes, mainly protease, amylase, glucanase and lipase (Formigoni et al. 1997, Shady 1997). This suggests the bacterium has the ability to lyse the shrimp cuticle constituted of protein, chitin (a polymer of $\mathrm{N}$-acetyl-glucosamine and glucosamine), calcium carbonate and lipid (Dennell 1960, Branson 1993).

Currently, probiotics are widely used in intensive culture systems to control water quality. All farms involved in this study were using probiotics on a regular basis. Probiotics used in these farms are specially formulated mixtures of beneficial bacteria and their enzymes, and Bacillus subtilis is a common component (Liong \& Subramaniam 1996). In the cases reported in our study, we noticed high numbers of white spots on the shrimp cuticle following the regular application of the probiotics in shrimp ponds. This fact, together with the isolation of $B$. subtilis from affected shrimp, has led

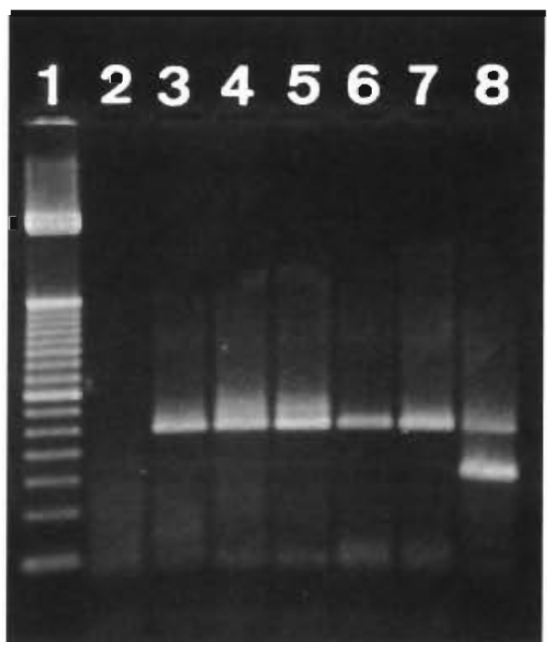

Fig. 13. PCR results. Lane 1: 50 bp DNA marker. Lane 2: negative control. Lanes 3-7: DNA from Samples 1 to 5 produced only the shrimp specific 232 bp PCR product, indicating a valid PCR reaction but a negative result for WSSV. Lane 8 positive control showing the shrimp-specific 232 bp product together with the 153 bp PCR product, indicating a positive WSSV reaction

Fig. 14. Penaeus monodon. (a) Dense white spots on the carapace (arrows) induced by WSSV (b) Wet mount microscopy of WSSV-induced spots that show a marginal nng (open arrows) and an enclosed central area with numerous melanized dots (arrows). Scale bar $=215 \mu \mathrm{m}$

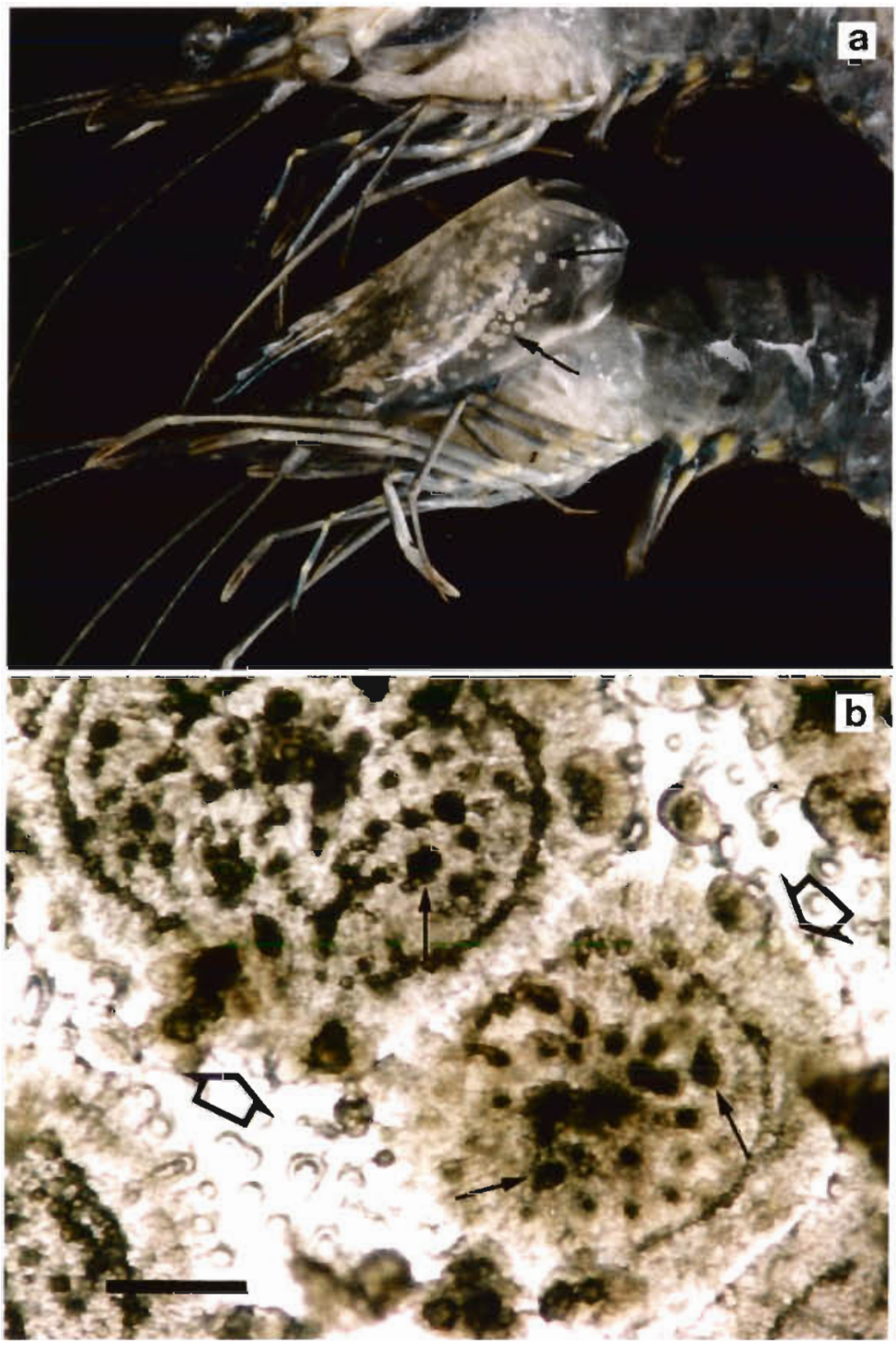


us to consider whether the occurrence of BWSS can be caused by the regular use of probiotics containing $B$. subtilis. However, further work would be necessary to determine this. It would be necessary to show genetic similarity between the $B$. subtilis isolated from the shrimp and that used in the probiotics. Experimental infection using $B$. subtilis isolates from shrimp and from probiotics would also be needed and these should also include tests to determine whether any environmental factors are involved in the disease process. Although Vibrio cholerae was also isolated in the present study, it is rarely recorded to cause disease problems in shrimp. For example, $V$. cholerae (non 01) has been reported to cause eyeball necrosis in cultured Penaeus chinensis (Zheng 1986). More studies are required to determine any possible interaction between $V$. cholerae and B. subtilis in the cause of BWSS.

Although BWSS is a non-systemic infection and lesions usually disappear after molting, severe infections together with poor husbandry may delay molting and affected shrimp may succumb to secondary infections resulting in low mortality rates. The shrimp cuticle acts as a barrier to bacteria and osmotic effects (Branson 1993), and the cuticular epidermis plays an important role in molting process (Van-Wormhoudt \& Bellon-Humbert 1994); thus, the abnormality caused by heavily infected cuticles and epidermis can disturb osmotic regulation and molting activity with serious consequences.

The recent widespread occurrence of BWSS in shrimp grow-out farms in Malaysia is of great concern because most farmers cannot distinguish BWSS from WSS. The situation can become even more complicated in the presence of both types of white spots. Based on previous severe losses due to the occurrence of WSS, farmers usually destroy shrimp showing clinical signs of white spots or carry out an emergency harvest. Since satisfactory yields can be obtained from ponds infected with BWSS, it would be a waste to destroy a crop mistakenly diagnosed as WSS. Thus, we recommend that farmers submit suspected WSS shrimp samples to the laboratory for confirmatory diagnosis. Similarly, laboratory technicians and shrimp health experts must be aware of potential confusion between BWSS and VWSS, and must not rely on visual examination for diagnostic purposes. Confirmatory diagnosis is crucial and can be made using wet mount microscopy, PCR or histopathology. It is possible that BWSS is widespread but has not been diagnosed correctly as everyone assumes that clinical signs of white spots on the cuticle are caused by WSSV. Discussions with Asian colleagues from Indonesia (Dr Agus Sunarto) and Sri Lanka (Dr Sunil Siriwardena) suggests that BWSS is also present in those countries. In addition, wet mount examination in our laboratory of sam- ples from Thailand and Saudi Arabia has also revealed the presence of BWSS (authors' unpubl. data).

Acknowledgements. We acknowledge Ms Chen Xia for her technical assistance with histology. Research grants for the project were provided by the Malaysian government research grant, Intensification of Research in Priority Areas (IRPA) No. 01-02-04-0171 and 01-02-04-0268.

\section{LITERATURE CITED}

Branson E (1993) Basic anatomy and physiology. In: Brown L (ed) Aquaculture for veterinarians, fish husbandry and medicine. Pergamon Press, Oxford, p 1-30

Chou HY, Huang CY, Wang CH, Chiang HC, Lo CF (1995) Pathogenicity of a baculovirus infection causing white spot syndrome in cultured penaeid shrimp in Taiwan. Dis Aquat Org 23:165-173

Cowan ST (1974) Cowan and Steel's manual for the identification of medical bacteria. Cambridge University Press, London

Dennell R (1960) Integument and exoskeleton. In: Waterman $\mathrm{TH}$ (ed) The physiology of crustacea. Academic Press, New York, p 449-472

Flegel TW (1997) Special topic review: major viral diseases of the black tiger prawn (Penaeus monodon) in Thailand. World J Microbiol Biotech 13:433-442

Formigoni A, Pezzi P, Tassinari M, Biagi G, Corradi F (1997) Effect of a probiotic on milk-fed calves. 1: Productive performances [digestive enzymes - Bacillus subtilis]. Atti Soc Ital Sci Vet 51:389-390 (in Italian with English abstract)

Hayat MA (1986) Basic techniques for transmission electron microscopy. Academic Press, Inc, San Diego, CA

Holt JG, Krieg NR, Sneath PHA, Staley JT, Williams ST (1994) Bergey's manual of determinative bacteriology, 9 th edn. Williams \& Wilkins, Baltimore

Huang J, Song XL, Yu J, Yang CH (1995) Baculoviral hypodermal and hematopoietic necrosis - study on the pathogen and pathology of the explosive epidemic disease of shrimp. Mar Fish Res 16(1):1-10 (in Chinese with English abstract)

Jang SS, Biberstein EL, Hirsh DC (1987) A diagnostic manual of veterinary clinical bacteriology and mycology. The Veterinary Medical Teaching Hospital, University of California, Davis

Lightner DV (1988) Bacterial shell (brown spot) disease of penaeid shrimp. In: Sindermann CJ, Lightner DV (eds) Disease diagnosis and control in North American marine aquaculture. Dev Aquacult Fish Sci 17:48-51

Lightner DV (1996) A handbook of pathology and diagnostic procedures for diseases of penaeid shrimp. World Aquaculture Society, Baton Rouge, LA

Liong PC, Subramaniam K (1996) Probiotics in shrimp farming. Paper presented on the seminar 'Development in Shrimp Farming', held in Institute of Advanced Studies, University of Malaya, 25 March 1996. Malaysian Fisheries Society, Kuala Lumpur

MacFaddin JF (1980) Biochemical tests for identification of medical bacteria. Williams \& Wilkins, Baltimore, MD

Murphy JA, Roomans GM (1984) Preparation of biological specimens for SEM. SEM Inc, AMF O'Hare, Chicago, IL

Shady TSM (1997) Studies on the application of Bacillus subtilis lipase in detergency. Ann Agric Sci (Cairo) 42(1): $73-80$

Takahashi Y, Itami T, Maeda M, Suzuki N, Kasornchandra J, 
Supamattaya K, Khongpradit R, Boonyaratpalin S, Kondo M, Kawai K, Kusuda R, Hirono I, Aoki T (1996) Polymerase chain reaction (PCR) amplification of bacilliform virus (RV-PJ) DNA in Penaeus japonicus Bate and systemic ectodermal and mesodermal baculovirus (SEMBV) DNA. in Penaeus monodon Fabricius. J Fish Dis 19:399-403

Van-Wormhoudt A, Bellon-Humbert C (1994) Crustacean farming: the biological basis. In: Barnabe $\mathrm{G}$ (ed) Aquaculture-biology and ecology of cultured species. Ellis Horwood, New York, p 175-223

Wang YG, Hassan MD, Shariff M, Saad MZ (1996) Cytopathological study of the systemic ectodermal and mesodermal baculovirus (SEMBV) infection in cultured black tiger shrimp Penaeus monodon in Peninsular Malaysia. In: Proceedings of 6 th Scientific Conference Electron Microscopy Society Malaysia held in Petaling Jaya, Selangor, Malaysia, October 26-27, 1996. University Malaya \& Electron Micro-

Editorial responsibility: Timothy Flegel,

Bangkok, Thailand scopy Society Malaysia, Kuala Lurnpur

Wang YG, Hassan MD, Shariff M, Zamri SM, Chen X (1999) Histopathology and cytopathology of white spot syndrome virus (WSSV) in cultured Penaeus monodon from peninsular Malaysia with emphasis on pathogenesis and the mechanism of white spot formation. Dis Aquat Org 39(1): $1-11$

Wongteerasupaya C. Vickers JE, Sriurairatana S, Nash GL, Akarajamorn A, Boonsaeng V, Panyim S, Tassanakajon A, Withyachumnarnkul B, Flegel TW (1995) A non-occluded systemic baculovirus that occurs in cells of ectodermal and mesodermal origin and causes high mortality in the black tiger prawn Penaeus monodon. Dis Aquat Org 21:69-77

Zheng GX (1986) Identification and pathogenicity of Vibrio cholerae (non-01) isolated from diseased penaeid shrimp. J Fish China/Shuichan Xuebao 10(2):195-203 (in Chinese with English abstract)

Submitted: October 4, 1999; Accepted: January 7, 2000

Proofs received from author(s): May 10, 2000 